\title{
sciendo
}

\section{Assessing the influence of Information and Communication Technologies on energy productivity}

\author{
Alexandra Catalina CHINIE \\ Bucharest University of Economic Studies, Bucharest, Romania \\ alexandra.chinie@fabiz.ase.ro
}

\begin{abstract}
The digitalization current is among one of the most relevant factors that currently drive transformation in the economy, with different degrees of impact across the main segments of the economy. As the topic of sustainability is now on the agenda of the biggest economic players, digitalization and the ability to leverage Information and Communication Technology opportunities have been recognized as drivers for innovation and change and a means to reach the sustainability goals. Reaching energy efficiency has been among the main objectives of both the public and the private sectors, leading to an increased interest in recognizing and capitalizing on energy efficiency opportunities. This in turn has an impact on the overall energy productivity, defined as the economic output per unit of energy. While this indicator has relevance at both micro and macro level, it is important to identify which makes some countries perform better than others. In the current economic context, studying how the performance of countries in the digital era correlates with the energy productivity can reveal further information on how it can be improved. The Networked Readiness Index is an indicator which assesses how well a country can capitalize on digital technologies and whether their usage of Information and Communication Technology has a relevant socio-economic impact. This paper analyzes which components that are assessed in a country's Networked Readiness Index might influence energy productivity. Based on a panel data analysis performed on European countries, the study identifies that the individual usage of Information and Communication Technologies, the business and innovation environment and the usage of ICT by the business segment could have an impact on the energy productivity of a country.
\end{abstract}

Keywords: energy productivity, Networked Readiness Index, information and communication technologies, digitalization, sustainability, panel data analysis

\section{Introduction}

Achieving an increased energy efficiency has been recognized as an objective that can support the transition towards a low-carbon economy and the realization of sustainable growth. In this respect, moving towards a 20\% increase in energy efficiency has been part of Europe's 2020 strategy (EC Directive, 2012). In November 2016, the Commission proposed a new target of 30\% energy efficiency (European Commission, 2016).

In the general context of sustainable development, a higher energy productivity can lead to a wide range of economic and social benefits (KAPSARC, 2015). The term has recognized an increased interest as a "cost-effective way to reduce global emissions of greenhouse gases" (McKinsey Global Institute, 2008), and an indicator that helps achieve environmental sustainability (Bean, 2014). Defined as ratio of output divided by energy consumption, it differentiates itself from energy efficiency by being used when the goal is to 
produce more using less or the same energy, instead of focusing on using less energy for the same outcome (Australian Government, 2018). Energy productivity is among the indicators published by the European Commission, measured as Euro per kilogram of oil equivalent or purchasing power standard per kilogram of oil equivalent (Eurostat, 2018a). In 2016, Ireland, the top performer for energy productivity in that year had a reported value 8.5 higher than the lowest performer, which suggests that differences between countries in the European space are still high (Eurostat, 2018a).

The evolution of information and communications technologies (ICT) and the development of digitalization have been associated with a better energy efficiency (Hilty et al., 2009) and increased economic growth (Romm, 2002). The European Commission has stated that "Information and Communication Technologies (ICTs) have an important role to play in reducing the energy intensity and increasing the energy efficiency of the economy" (European Commission, 2008), recognizing ICT as an important means to achieve its goals for sustainable development.

In an attempt to assess the level of development of ICT and digitalization in a country, composite indicators have been defined, such as the Networked Readiness Index published by the World Economic Forum (World Economic Forum, 2018) and the Digital Economy and Society Index, published by the European Commission (European Commission, 2018). The purpose of this paper is to complement the current body of research concerning the influence of ICT on energy and economic growth goals, by analyzing the influence that the factors which measure the ICT sector have on energy productivity, using a panel data analysis on 35 countries from Europe. Studying the ICT indicators which have an impact on energy productivity can reveal which aspects of the information and technology field could support a higher environmental and economic performance.

\section{Literature review}

Researchers have been studying means to achieve sustainable development, such as fostering the circular economy and increasing the recycling rate (Pelau and Chinie, 2018) or increasing the consumption of energy from renewable sources (Pelau and Pop, 2018). Another way to achieve sustainable development is to obtain economic growth with limited input. Energy productivity can be higher in some countries as opposed to others because of the structure of the economy, where the services sector has a higher impact on GDP than energy intensive industrial sectors (KAPSARC, 2014). While the development of the ICT sector is correlated to the growth of ICT services, the use of information and communication technologies also has an impact on other services (Romm, 2002; Sapprasert, 2007).

Information and communication technologies contribute to the sustainable development of an economy by supporting innovation in companies (Ollo-López and Aramendia-Muneta, 2012), reducing carbon emissions (Higón et al., 2017) and improving energy efficiency (Morán et al., 2016; EC Recommendation, 2014). ICT is consequently considered an inseparable component of smart cities (Bibri and Krogstie, 2017).

Mitchell (2000) has identified five key points through which the ICT sector positively influences the environment, by reducing energy consumption: dematerialization, demobilization, mass customization, intelligent operation and soft transformation. Dematerialization is the process through which material goods or services are replaced by digital ones or miniaturized (Kramers, 2014), while demobilization is the case where 
transportation can be reduced by telecommunications (Mitchell, 2000). Mass customization is possible through "smart machines" that deliver "intelligent adaptation and automated personalization" (Mitchell, 2000). Intelligent operation implies a more efficient use of water and energy, while soft transformation is related to information, digital connectivity and a good management of limited resources as the basis for the development of future cities (Mitchell, 2000).

In order to analyze the impact that information and communication technologies have in an economy, indicators have been defined for the measurement of the development of the ICT sector and the degree to which ICT products and services are used.

The ICT Development index is published by the United Nations International Telecommunication Union and it is based on ICT indicators which are grouped in three subindexes: access, intensity and skills (International Telecommunications Union, 2018).

The Networked Readiness Index measures how well an economy is using ICT "to boost competitiveness and well-being" and evaluates if a country has the ability to fully leverage on digital technologies and if these have an impact on the economy and society (World Economic Forum, 2018). Drivers for digital technologies are grouped into three sub-indexes: the overall environment, readiness (which includes infrastructure, affordability and skills) and usage (which encompasses individuals, business and government). Also, the economic and social impacts are measured in a separate sub-index (World Economic Forum, 2018).

The European Commission publishes the Digital Economy and Society Index (DESI), which "summarises relevant indicators on Europe's digital performance and tracks the evolution of EU member states in digital competitiveness" (European Commission, 2018). The DESI sub-indexes are connectivity, human capital, use of internet services, integration of digital technology and digital public services.

In a study performed by Yan et al. (2018), ICT development, measured based on a patent-based indicator, has been positively linked to an accumulation of energy productivity. Studying which aspects of the ICT sector influence energy productivity on a macroeconomic level could reveal relevant information for achieving a better performance for this indicator.

\section{Methodology}

The main objective of the paper is to analyze what aspects related to the ICT sector might influence energy productivity. In this respect, the following regression model for a panel data analysis was used:

$X_{\text {EPROD,it }}=\beta_{1} X_{\text {Pillar1,it }}+\beta_{2} X_{\text {Pillar2,it }}+\beta_{3} X_{\text {Pillar3,it }}+\beta_{4} X_{\text {Pillar4,it }}+\beta_{5} X_{P i l l a r 5, i t}+\beta_{6} X_{P i l l a r 6, t}+\beta_{7} X_{P i l l a r 7, t t}+\beta_{8} X_{P i l l a r 8, i t}$ $+\beta_{9} X_{P \text { illar9,it }}+\beta_{10} X_{P i l l a r 10, i t}+\beta_{11} X_{G D P . g r o w t h, i t}+c_{1}$

having $i=$ number of countries included in the analysis, $\mathrm{t}=$ time unit for the analyzed period

Energy productivity is the dependent variable. The Eurostat indicator measured as Euro per kilogram of oil equivalent was used for the analysis (Eurostat, 2018a).

The 10 pillars of the NRI are the independent variables of the model: Political and regulatory environment (Pillar 1), Business and innovation environment (Pillar 2), Infrastructure (Pillar 3), Affordability (Pillar 4), Skills (Pillar 5), Individual usage (Pillar 6), Business usage (Pillar 7), Government usage (Pillar 8), Economic impacts (Pillar 9) and Social impacts (Pillar 10) (World Economic Forum Data, 2018). In order to ensure a better accuracy of the model, the regression model included the control variable GDP growth, collected from 
the Eurostat database (Eurostat, 2018b). For each of the eleven independent variables, a coefficient $\beta \mathrm{i}, \mathrm{i}=1, . ., 10$ was defined. The value and significance of the $\beta$ coefficients have been determined based on the panel data analysis, which was performed in R.

The energy productivity indicator from the Eurostat Database, for the time frame 2012-2016 (updated on 26.10.2018), was taken into account for the study (Eurostat, 2018a). Thirty-five countries were included in the model: Albania, Austria, Belgium, Bulgaria, Croatia, Cyprus, Czech Republic, Denmark, Estonia, Finland, France, Germany, Greece, Hungary, Iceland, Ireland, Italy, Latvia, Lithuania, Luxembourg, Macedonia, Malta, Montenegro, Netherlands, Norway, Poland, Portugal, Romania, Serbia, Slovak Republic, Slovenia, Spain, Sweden, Turkey and the United Kingdom.

The NRI pillars (subcategories) were collected for the same time interval from the website of the World Economic Forum (World Economic Forum Data, 2018). The score of the pillars is the arithmetic mean of the scores for the individual indicators that constitute the subcategory, unless otherwise specified. Some of these indicators are scores from 1-7, while others were transformed using the minimum and maximum method (World Economic Forum, 2016). The NRI pillars (subcategory) belong to four sub-indexes: environment, readiness, usage and impact (World Economic Forum, 2016). Only the aggregated scores for the NRI pillars were used for the analysis.

Table 1. Independent variables - Networked Readiness Index Pillars

\begin{tabular}{|l|l|}
\hline Pillar 1: Political and regulatory & Effectiveness of law-making bodies, 1-7 (best) \\
environment & Laws relating to ICTs, 1-7 (best) \\
& Judicial independence, 1-7 (best) \\
& Efficiency of legal system in settling disputes, 1-7 (best) \\
& Efficiency of legal system in challenging regulations, 1-7 (best) \\
& Intellectual property protection, 1-7 (best) \\
& Software piracy rate, \% software installed \\
& Number of procedures to enforce a contract \\
& Number of days to enforce a contract \\
\hline Pillar 2: Business and & Availability of latest technologies, 1-7 (best) \\
& Venture capital availability, 1-7 (best) \\
& Total tax rate, \% profits \\
& Number of days to start a business \\
& Number of procedures to start a business \\
& Intensity of local competition, 1-7 (best) \\
& Tertiary education gross enrollment rate, \% \\
& Quality of management schools, 1-7 (best) \\
& Government procurement of advanced technology products, 1-7 (best) \\
\hline Pillar 3: Infrastructure & Electricity production, kWh/capita \\
& Mobile network coverage, \% population \\
& International Internet bandwidth, kb/s per user \\
& Secure Internet servers/million population \\
\hline Pillar 4: Affordability & Prepaid mobile cellular tariffs, PPP \$/min. \\
& Fixed broadband Internet tariffs, PPP \$/month \\
& Internet and telephony sectors competition index, 0-2 (best) \\
\hline $5^{\text {th }}$ pillar: Skills & Quality of educational system, 1-7 (best) \\
& Quality of math and science education, 1-7 (best) \\
& Secondary education gross enrollment rate, \% \\
& Adult literacy rate, \% \\
\hline pillar: Individual usage & Mobile phone subscriptions per 100 population \\
\hline
\end{tabular}




\begin{tabular}{|c|c|}
\hline & $\begin{array}{l}\text { Percentage of individuals using the Internet } \\
\text { Percentage of households with computer } \\
\text { Fixed broadband Internet subscriptions per } 100 \text { population } \\
\text { Mobile broadband Internet subscriptions per } 100 \text { population } \\
\text { Use of virtual social networks, } 1-7 \text { (best) }\end{array}$ \\
\hline $7^{\text {th }}$ pillar: Business usage & $\begin{array}{l}\text { Firm-level technology absorption, 1-7 (best) } \\
\text { Capacity for innovation, 1-7 (best) } \\
\text { PCT patent applications per million population } \\
\text { ICT use for business-to-business transactions, 1-7 (best) } \\
\text { Business-to-consumer Internet use, 1-7 (best) } \\
\text { Extent of staff training, 1-7 (best) }\end{array}$ \\
\hline $8^{\text {th }}$ pillar: Government usage & $\begin{array}{l}\text { Importance of ICTs to government vision, 1-7 (best) } \\
\text { Government Online Service Index, 0-1 (best) } \\
\text { Government success in ICT promotion, 1-7 (best) }\end{array}$ \\
\hline $9^{\text {th }}$ pillar: Economic impacts & $\begin{array}{l}\text { Impact of ICTs on business models, } 1-7 \text { (best) } \\
\text { ICT PCT patent applications per million population } \\
\text { Impact of ICTs on organizational models, 1-7 (best) } \\
\text { Knowledge intensive jobs, \% workforce }\end{array}$ \\
\hline $10^{\text {th }}$ pillar: Social impacts & $\begin{array}{l}\text { Impact of ICTs on access to basic services, 1-7 (best) } \\
\text { Internet access in schools, } 1-7 \text { (best) } \\
\text { ICT use and government efficiency, 1-7 (best) } \\
\text { E-Participation Index, } 0-1 \text { (best) }\end{array}$ \\
\hline
\end{tabular}

Source: World Economic Forum (2016)

One of the reasons for which the Networked Readiness Index was used over the European Commission's Digital Economy and Society Index was the fact that available DESI data was available starting with 2014, thus using the NRI would provide for a larger dataset to be analyzed (European Commission, 2018b)

The use of OLS for the analysis would have generated biased results in the presence of unobserved heterogeneity, so random effects and fixed effects models were considered in order to have consistent results.

\section{Results and discussion}

Statistical analysis of the data

The descriptive analysis of data includes the variation of the variables and the correlation of the independent variables (Table 2 and Table 3 ).

The dependent variable energy productivity has a mean of 6.71 and a standard deviation of 3.36. The minimum value for this variable, 1.80, refers to Iceland for years 2012 and 2013. The maximum value, 17.00, is the energy productivity for Ireland, for year 2016. Ireland has also had the highest energy productivity for year 2015, at a value of 16.9 kgoe.

Variable GDP growth has a mean of 1.94 and a standard deviation of 2.97. The minimum value is the GDP growth of Greece in 2012, -7.3. The maximum value is the GDP growth of Ireland in 2015.

The aggregated NRI index has a minimum value of 3.64, which is the score for Serbia for year 2012 and a maximum value of 6.04, the score for Finland for 2014.

The $1^{\text {st }}$ pillar of the Networked Readiness Index, "Political and regulatory environment", has a minimum value of 3.05, which is the score for Serbia for 2012. The maximum value is 5.94, the score for Luxembourg in 2016. The $2^{\text {nd }}$ pillar, "Business and innovation environment", has a minimum value of 3.84, the score for Serbia for year 2012, 
and the maximum value of 5.48, which is the score for the United Kingdom for year 2016. The $3^{\text {rd }}$ pillar, "Infrastructure", has a minimum value of 3.49, the score for Albania for year 2014, and a maximum value of 7, which is the score for Norway (years 2015 and 2016). The $4^{\text {th }}$ pillar, "Affordability", has a minimum value of 3.32, the score for the Slovak Republic (year 2013) and a maximum value of 6.87, the score for Turkey for year 2016.

Table 2. Statistical variation of variables

\begin{tabular}{|l|r|r|r|r|}
\hline \multicolumn{1}{|c|}{ Variable } & \multicolumn{1}{c|}{ Minimum } & \multicolumn{1}{c|}{ Maximum } & \multicolumn{1}{c|}{ Mean } & \multicolumn{1}{c|}{ Std. Deviation } \\
\hline EPROD & 1.80 & 17.00 & 6.7063 & 3.35727 \\
\hline PILLAR1 & 3.05 & 5.94 & 4.4068 & .86809 \\
\hline PILLAR2 & 3.84 & 5.48 & 4.7492 & .39785 \\
\hline PILLAR3 & 3.49 & 7.00 & 5.5335 & .90231 \\
\hline PILLAR4 & 3.32 & 6.87 & 5.5505 & .70325 \\
\hline PILLAR5 & 4.54 & 6.55 & 5.5775 & .40962 \\
\hline PILLAR6 & 2.93 & 6.86 & 5.2875 & .88084 \\
\hline PILLAR7 & 2.70 & 6.22 & 4.3155 & .91325 \\
\hline PILLAR8 & 3.11 & 5.60 & 4.3767 & .67620 \\
\hline PILLAR9 & 2.52 & 6.15 & 4.1739 & .90793 \\
\hline PILLAR10 & 3.11 & 6.08 & 4.6103 & .75947 \\
\hline GDP growth & -7.30 & 25.10 & 1.9389 & 2.97383 \\
\hline NRI & 3.64 & 6.04 & 4.7960 & .65072 \\
\hline
\end{tabular}

Source: Authors' own research

The $5^{\text {th }}$ pillar of the NRI, "Skills", has a minimum value of 4.54, the score for Turkey for year 2012, and a maximum value of 6.55, which is the score for Finland, for year 2014. The $6^{\text {th }}$ pillar, "Individual usage", has a minimum value of 2.93, the score for Albania for year 2013 and a maximum value of 6.86, the score for Denmark for 2016. The $7^{\text {th }}$ pillar, "Business usage", has a minimum value of 2.70, the score for Serbia for 2013 and a maximum value of 6.22, the score for Sweden for year 2012. The minimum value for the $8^{\text {th }}$ pillar, "Government usage", is 3.11, the score for Bulgaria for year 2015, while the maximum value is 5.60, the score for Sweden for year 2014. The 9th pillar, "Economic impacts", has a minimum value of 2.52 , the score for Albania for year 2015, and a maximum value of 6.15, the score for Sweden for year 2012. The $10^{\text {th }}$ pillar, which refers to the social impact of ICT, has a minimum value of 3.11, which is the score for Serbia for year 2012, and a maximum value of 6.08, the score for the Netherlands for year 2013. The values for the $10^{\text {th }} \mathrm{NRI}$ pillar for the Netherlands for years 2014 - 2016 are close to the maximum value - 6.06 for 2014 and 6.07 for 2015 and 2016. 
Table 3. Correlation matrix for the variables

\begin{tabular}{|c|c|c|c|c|c|c|c|c|c|c|c|}
\hline & $\begin{array}{l}\text { GDP- } \\
\text { growth }\end{array}$ & P1 & P2 & P3 & P4 & P5 & P6 & P7 & P8 & P9 & P10 \\
\hline GDP_growth & 1 & & & & & & & & & & \\
\hline PILLAR1 & .079 & 1 & & & & & & & & & \\
\hline PILLAR2 & .143 & $.791^{* *}$ & 1 & & & & & & & & \\
\hline PILLAR3 & .040 & $.851^{* *}$ & $.734^{* *}$ & 1 & & & & & & & \\
\hline PILLAR4 & .004 & $.377^{* *}$ & $.359^{* *}$ & $.332^{* *}$ & 1 & & & & & & \\
\hline PILLAR5 & .030 & $.726^{* *}$ & $.704^{* *}$ & $.734^{* *}$ & $.330^{* *}$ & 1 & & & & & \\
\hline PILLAR6 & .112 & $.832^{* *}$ & $.743^{* *}$ & $.845^{* *}$ & $.350^{* *}$ & $.680^{* *}$ & 1 & & & & \\
\hline PILLAR7 & .019 & $.937^{* *}$ & $.761^{* *}$ & $.848^{* *}$ & $.402^{* *}$ & $.752^{* *}$ & $.837^{* *}$ & 1 & & & \\
\hline PILLAR8 & .094 & $.861^{* *}$ & $.746^{* *}$ & $.690^{* *}$ & $.312^{* *}$ & $.580^{* *}$ & $.709^{* *}$ & $.773^{* *}$ & 1 & & \\
\hline PILLAR9 & .037 & $.938^{* *}$ & $.794^{* *}$ & $.849^{* *}$ & $.360^{* *}$ & $.767^{* *}$ & $.867^{* *}$ & $.957^{* *}$ & $.821^{* *}$ & 1 & \\
\hline PILLAR10 & .081 & $.844^{* *}$ & $.773^{* *}$ & $.725^{* *}$ & $.362^{* *}$ & $.650^{* *}$ & $.787^{* *}$ & $.808^{* *}$ & $.894^{* *}$ & $.849^{* *}$ & 1 \\
\hline
\end{tabular}

PICBE | 521

Source: Authors' own research

The correlation matrix reveals a strong correlation between the independent variables, with the exception of the 4 th pillar, affordability. This correlation indicates that the influence of the NRI pillars has to be tested for each pillar individually.

\section{Results of the panel data analysis with random effect}

As expected, the influence of the control variable GDP growth on energy productivity is statistically significant. This was tested within the fixed effects model and the random effects model. The result of the Hausman test showed that the random effects model is more accurate, with a Chisq of 0.000 and a p-value of 0.98 . The regression model shows a positive influence of GDP growth on the dependent variable "Energy productivity".

Table 4. Regression model for control variable GDP growth - random effects

\begin{tabular}{|l|l|l|l|l|}
\hline & Estimate & Std. Error & t-value & Significance \\
\hline Constant & 6.472 & 0.573 & 11.304 & $0.000^{* * *}$ \\
\hline GDP growth & 0.121 & 0.018 & 6.855 & $0.000^{* * *}$ \\
\hline R-Squared: 0.214 & \\
F-statistic: 46.995 on 1 and $173 \mathrm{DF}$, p-value: 0.000 \\
Significance codes: ${ }^{(* * *)} 0.001^{(* *)} 0.01^{\text {(*) } 0.05}$
\end{tabular}

Source: Authors' own research

Before analyzing the results of the regression model including the ten independent variables and the control variable GDP growth, the influence of the overall NRI index on energy productivity was tested with a fixed effects model and a random effects model. 
Table 5. Fixed effects model for dependent variable Energy Productivity

\begin{tabular}{|l|l|l|l|l|}
\hline & Estimate & Std. Error & t-value & Significance \\
\hline NRI & 0.976 & 0.379 & 2.577 & $0.011^{*}$ \\
\hline GDP growth & 0.106 & 0.018 & 5.819 & $0.000^{* * *}$ \\
\hline Total Sum of Squares: 52.628 \\
Residual Sum of Squares: 37.619 \\
R-Squared: 0.285 \\
Adj. R-Squared: 0.099 \\
F-statistic: 27.529 on 2 and 138 DF, p-value: 0.000 \\
\hline Significance codes: ${ }^{* * * \prime} 0.001^{* * \prime} 0.01^{* \prime} 0.05$ \\
\hline
\end{tabular}

Source: Authors' own research

Table 6. Random effects model for dependent variable Energy Productivity

\begin{tabular}{|c|c|c|c|c|}
\hline & Estimate & Std. Error & t-value & Significance \\
\hline (Intercept) & 0.086 & 1.703 & 0.051 & 0.960 \\
\hline NRI & 1.340 & 0.342 & 3.918 & $0.000^{* * *}$ \\
\hline GDP growth & 0.101 & 0.018 & 5.546 & $0.000 * * *$ \\
\hline $\begin{array}{l}\text { Total Sum of } \\
\text { Residual Sun } \\
\text { R-Squared: } \\
\text { Adj. R-Squar } \\
\text { F-statistic: } 3 \\
\end{array}$ & $\begin{array}{l}\text { uares: } 65 \\
\text { Squares: } \\
269 \\
0.260 \\
47 \text { on } 2 \text { and }\end{array}$ & $2 \mathrm{DF}, \mathrm{p}-\mathrm{val}$ & 0.000 & \\
\hline Significance & es: ‘***’ 0. & ‘**’ $0.01^{\text {‘*’ }}$ & & \\
\hline
\end{tabular}

Source: Authors' own research

In order to choose the most appropriate model for the analysis, a Hausman test was performed. With a Chisq of 4.976 and a p-value of 0.083 , results of the test showed that the random effects model is more accurate and it was also used for the further analysis of all NRI pillars.

Since an influence of the NRI index on energy productivity could be proven, the influence of all pillars that the NRI score is composed of was tested. In order to observe the influence of each of the $10 \mathrm{NRI}$ pillars, models 1-10 test panel regressions including each of the independent variables and the control variable GDP growth. The control variable is statistically significant in all of the models, with relatively stable coefficients.

Models 1 and 2, which analyze the influence that the political and regulatory environment (Pillar 1) and the business and innovation environment (Pillar 2) have on energy productivity, show positive statistically significant $\beta$ coefficients. The $F$ factors of the regressions are statistically significant. Infrastructure is analyzed in model 3 , where the $\beta$ coefficient for the independent variable Pillar 3 is statistically significant and shows a positive influence of infrastructure on energy productivity. Affordability and skills were tested in models 4 and 5, where no statistically significant $\beta$ coefficients resulted. Model 6 analyzed the relationship between the individual usage of ICT (Pillar 6) and energy productivity. A positive relation between the independent variable and energy productivity resulted from the regression analysis, where the coefficient for Pillar 6 is statistically significant. The $\mathrm{F}$ factor is also statistically significant and higher than in the other models, proving a good accuracy of the model. A positive relation between business usage and energy 
productivity can be observed in Model 7. No significant influence of independent variable "government usage" was identified in the regression of Model 8. The economic and social impacts of ICT (Pillar 9 and Pillar 10) have statistically significant $\beta$ coefficients in Models 9 and 10, suggesting a positive influence on energy productivity, and the F factors are higher than the F factor of Model 3.

Model 11 includes the independent variables from the previous models that had the highest $\mathrm{F}$ factors - business and innovation environment, individual usage and business usage, and the control variable GDP growth. In this case, the influence of Pillar 2 on the energy productivity is no longer significant, which could be caused by the high correlation with the other independent variables. Consequently, Pillar 2 was excluded from the analysis in Model 12, where only the influences of Pillar 6 and Pillar 7 were tested. However, the F factor of the regression, at 28.416, is lower than those of models 6 and 7, where the independent variables have been analyzed individually, although the R square is higher.

Table 7. Regression models for panel data with dependent variable Energy Productivity (Models 1-6)

\begin{tabular}{|c|c|c|c|c|c|c|}
\hline & Model 1 & Model 2 & Model 3 & Model 4 & Model 5 & Model 6 \\
\hline \multirow{2}{*}{$\begin{array}{l}\text { GDP } \\
\text { growth }\end{array}$} & $0.126^{* * *}$ & $0.01^{* * *}$ & $0.116^{* * *}$ & $0.121^{* * *}$ & $0.115^{* * *}$ & $0.082^{* * *}$ \\
\hline & 1.533 & 0.018 & 0.018 & 0.018 & 0.018 & 0.018 \\
\hline \multirow[t]{2}{*}{ PILLAR 1} & $1.094^{* *}$ & & & & & \\
\hline & 0.330 & & & & & \\
\hline \multirow[t]{2}{*}{ PILLAR 2} & & $1.197^{* * *}$ & & & & \\
\hline & & 0.305 & & & & \\
\hline \multirow[t]{2}{*}{ PILLAR3 } & & & $0.477^{*}$ & & & \\
\hline & & & 0.232 & & & \\
\hline \multirow[t]{2}{*}{ PILLAR4 } & & & & 0.002 & & \\
\hline & & & & 0.110 & & \\
\hline \multirow[t]{2}{*}{ PILLAR5 } & & & & & 0.353 & \\
\hline & & & & & 0.271 & \\
\hline \multirow[t]{2}{*}{ PILLAR6 } & & & & & & $0.717^{* * *}$ \\
\hline & & & & & & 0.140 \\
\hline \multicolumn{7}{|l|}{ PILLAR7 } \\
\hline \multirow[t]{2}{*}{ Constant } & 1.639 & 0.835 & $3.843^{* *}$ & $6.464^{* * *}$ & $4.517^{* *}$ & $2.755^{* *}$ \\
\hline & 1.533 & 1.530 & 1.378 & 0.834 & 1.598 & 0.881 \\
\hline F stat & $\begin{array}{l}28.315 \\
0.00^{* * *}\end{array}$ & $\begin{array}{l}32.462 \\
0.00^{* * *}\end{array}$ & $\begin{array}{l}24.904 \\
0.00^{* * *}\end{array}$ & $\begin{array}{l}23.207 \\
0.00^{* * *}\end{array}$ & $\begin{array}{l}23.748 \\
0.00^{* * *}\end{array}$ & $\begin{array}{l}39.207 \\
0.00^{* * *}\end{array}$ \\
\hline R square & 0.248 & 0.274 & 0.225 & 0.213 & 0.216 & 0.313 \\
\hline
\end{tabular}

Source: Authors' own research

Table 8. Regression models for panel data with dependent variable Energy Productivity (Models 7-12)

\begin{tabular}{|l|l|l|l|l|l|l|}
\hline & Model 7 & Model 8 & Model 9 & Model 10 & Model 11 & Model 12 \\
\hline $\begin{array}{l}\text { GDP } \\
\text { growth }\end{array}$ & $0.108^{* * *}$ & $0.121^{* * *}$ & $0.111^{* * *}$ & $0.110^{* * *}$ & $0.081^{* * *}$ & 0.081 \\
\hline & 0.018 & 0.018 & 0.018 & 0.018 & 0.018 & $0.00^{* * *}$ \\
\hline PILLAR2 & & & & & 0.126 & \\
\hline & & & & & 0.412 & \\
\hline PILLAR6 & & & & & $0.552^{* *}$ & $0.588^{* * *}$ \\
\hline & & & & & 0.193 & 0.150 \\
\hline PILLAR7 & $1.224^{* * *}$ & & & & $0.695^{*}$ & $0.720^{*}$ \\
\hline
\end{tabular}




\begin{tabular}{|l|l|l|l|l|l|l|}
\hline & 0.299 & & & & 0.320 & 0.313 \\
\hline PILLAR8 & & -0.008 & & & & \\
\hline & & 0.212 & & & & \\
\hline PILLAR9 & & & $0.748^{* *}$ & & & \\
\hline & & & 0.258 & & & \\
\hline PILLAR10 & & & & $0.395^{*}$ & & \\
\hline & & & & 0.164 & & \\
\hline Constant & 1.215 & $6.505^{* * *}$ & $3.367^{* *}$ & $4.672^{* * *}$ & 0.039 & 0.330 \\
\hline & 0.377 & 1.059 & 1.184 & 0.917 & 1.725 & 1.361 \\
\hline F stat & 32.241 & 22.093 & 27.233 & 26.262 & 21.250 & 28.416 \\
& $0.00^{* * *}$ & $0.00^{* * *}$ & $0.000^{* * *}$ & $0.00^{* * *}$ & $0.00^{* * *}$ & $0.00^{* * *}$ \\
\hline R square & 0.273 & 0.256 & 0.262 & 0.270 & 0.333 & 0.333 \\
\hline Significance codes: ${ }^{* * * \prime} 0.001^{* * \prime} 0.01^{* * \prime} 0.05$ & & \\
\hline
\end{tabular}

Source: Authors' own research

The analysis of the 12 models shows the NRI pillars with the most significant influence on energy productivity are individual usage, the business and innovation environment and the business usage, with R-scores of $0.313,0.274$ and 0.273 . Higher scores for these factors lead to a higher energy productivity. Models 9 and 10 also suggest that the economic and social impacts of ICT have a positive influence on energy productivity, although their impact is less significant than those of pillar 6, 2 and 7.

The positive influence on energy productivity provided by Pillar 6, ICT individual usage, which includes indicators related to internet usage and internet infrastructure in its computation, as well as the influence of Pillar 7, business usage, which includes indicators such as business-to-consumer internet use and firm-level absorption, suggests an alignment with the conclusion of Romm et al. (2008), who identified that the internet can help lower electricity intensity. The influence that ICT usage and its impact on the economy have on energy productivity also confirms the results of Yan et al. (2018), which showed a positive relation between ICT development and energy productivity. However, a closer analysis of the indicators that make up these pillars needs to be carried out.

\section{Conclusions}

A perspective on which aspects related to the ICT sector might influence energy productivity could support the outline of measures which are aimed at increasing energy productivity, thus achieving higher economic output with limited energy consumption.

Results of the study confirm the research of Yan et al. (2018), who identified a positive impact of ICT development on energy productivity. The analysis provides a different perspective on this relation by analyzing the aspects that determine a developed ICT sector and can contribute to a higher energy productivity.

There are several limitations to the study: a high correlation of the independent variables, the Networked Readiness Index pillars, which only permitted an individual analysis for each of these. The sample size is small - including data from the following years could provide a more accurate model. Also, an addition of more control variables could increase the accuracy of the models and should be included in future analysis. 
Out of the most significant factors which seem to impact energy productivity, two are related to ICT usage and one to the environment which helps the ICT sector develop - results of the study show that high scores for the Networked Readiness Index pillars "individual usage", "business and innovation environment" and ICT "business usage" have a positive effect on energy productivity. The impact that ICT has on the economy and society also

showed a positive influence on energy productivity, although smaller than for the previously mentioned categories. No influence of affordability, skills and government usage of ICT on energy productivity could be proven by the model.

These outcomes suggest that a positive impact on energy productivity could be provided by increasing the population's individual usage of ICT (through internet and mobile phone access), fostering a competitive, innovative business environment (which implies, among others, availability of venture capital and new technologies) and supporting ICT usage by companies (which includes, among others, technology absorption and PCT patent applications). In order to make a more accurate assessment of the impact that dimensions related to ICT development have on energy productivity, the influence of the individual indicators that make up these NRI categories needs to be assessed and can constitute the basis for a future research.

\section{References}

Australian Government (2018). Energy productivity and energy efficiency, Department of the Environment and Energy. Retrieved from: https://www.energy.gov.au/governmentpriorities/energy-productivity-and-energy-efficiency

Bean, P. (2014). The Case for Energy Productivity: It's not Just Semantics, King Abdullah Petroleum Studies and Research Center Discussion Paper KS-1402-DP01B.

Bibri, S.E. \& Krogstie, J. (2017). Smart sustainable cities of the future: An extensive interdisciplinary literature review. Sustainable Cities and Society, 31, 183-212.

[Data] Eurostat (2018a). Energy Productivity. Retrieved from https://ec.europa.eu/eurostat/tgm/table.do?tab=table\&init=1\&language=en\&pcode =sdg_07_30\&plugin $=1$

[Data] Eurostat (2018b). Real GDP growth rate - volume. Retrieved from https://ec.europa.eu/eurostat/tgm/table.do?tab=table\&init=1\&plugin=1\&language $=$ en\&pcode $=$ tec 00115

[Data] World Economic Forum Data http://www3.weforum.org/docs/GITR2016/WEF_NRI_2012-

2016_Historical_Dataset.xlsx

EC Directive (2012). Directive 2012/27/EU of the European Parliament and of the Council of 25 October 2012 on energy efficiency, amending Directives 2009/125/EC and 2010/30/EU and repealing Directives 2004/8/EC and 2006/32/EC

EC Recommendation (2014). Commission Recommendation of 10 October 2014 on the Data Protection Impact Assessment Template for Smart Grid and Smart Metering Systems (2014/724/EU) 
European Commission (2008). Addressing the challenge of energy efficiency through Information and Communication Technologies, Communication from the Commission to the European Parliament, The Council, The European Economic and Social Committee and the Committee of the Regions, Brussels, 13.5.2008, COM (2008) 241 final

European Commission (2016). Putting energy efficiency first: consuming better, getting cleaner, European Commission - Fact Sheet (http://europa.eu/rapid/pressrelease_MEMO-16-3986_en.htm)

European Commission (2018a). The Digital Economy and Society Index (DESI), Online at: https://ec.europa.eu/digital-single-market/en/desi

European Commission (2018b). Digital Economy and Society Index, Online at: https://digitalagenda-data.eu/datasets/desi/indicators\#desi-overall-index

International Telecommunications Union (2018). The ICT Development Index (IDI): conceptual framework and methodology, Retrieved from https://www.itu.int/en/ITU-

D/Statistics/Pages/publications/mis2015/methodology.aspx

KAPSARC (2015). Global shift: The energy productivity transformation, KAPSARC Energy Workshop Series, KS-1517-WB15A, Retrieved from: https://www.kapsarc.org/research/publications/global-shift-the-energyproductivity-transformation/

Higón, D.A., Gholami, R. \& Shirazi, F. (2017). ICT and environmental sustainability: A global perspective. Telematics and Informatics, 34(4), 85-95.

Hilty, L.M., Coroama, V.C, Ossés De Eicker, M., Ruddy, T.F., Thiébaud (-Müller), E. (2009). The Role of ICT in Energy Consumption and Energy Efficiency. ICT-ENSURE: European ICT Environmental Sustainability Research, Project Number 224017.

Kramers, A., Höjer, M., Lövehagen, N. \& Wangel, J. (2014). Smart sustainable cities - Exploring ICT solutions for reduced energy use in cities. Environmental Modelling \& Software, 56, June 2014, 52-62.

McKinsey Global Institute (2008). The Case for Investing in Energy Productivity. Eds: Farrell, D., Remes, J., Bressand, F., Laabs, M. \& Sundaram, A., February 2008. Retrieved from https://www.mckinsey.com/business-functions/sustainability-and-resourceproductivity/our-insights/the-case-for-investing-in-energy-productivity

Mitchell, W.J. (2000). E-topia, "Urban Life, Jim - but Not as We Know it", The MIT Press, Cambridge Mass.

Morán, A.J., Profaizer, P., Zapater, M.H., Valdavida, M.A., Bribián, I.Z. (2016). Information and Communications Technologies (ICTs) for energy efficiency in buildings: Review and analysis of results from EU pilot projects, Energy and Buildings, 127, 1 September 2016, 128-137.

Ollo-López, A. \& Aramendía-Muneta, M. E. (2012). ICT impact on competitiveness, innovation and environment. Telematics and Informatics, 29(2), May 2012, 204-210.

Pelau, C. \& Chinie, A.C. (2018). Econometric Model for Measuring the Impact of the Education Level of the Population on the Recycling Rate in a Circular Economy. Amfiteatru Economic, 20(48), pp. 340-355. 
Pelau, C. \& Pop, N.Al. (2018). Implications for the energy policy derived from the relation between the cultural dimensions of Hofstede's model and the consumption of renewable energies, Energy Policy, 118, July 2018, 160-168.

Romm, J. (2002). The internet and the new energy economy. Resources, Conservation and Recycling, 36(3), October 2002, 197-210.

Sapprasert, K. (2007). The impact of ICT on the growth of the service industries, Working

PICBE $\mid 527$ Papers on Innovation Studies 20070531, Centre for Technology, Innovation and Culture, University of Oslo, revised Apr 2010.

World Economic Forum (2018). What is 'networked readiness' and why does it matter?, Retrieved from https://www.weforum.org/agenda/2016/07/what-is-networkedreadiness-and-why-does-it-matter/

World Economic Forum (2016). The Global Information Technology Report 2016, Innovating in the Digital Economy, Eds: Baller, S., Dutta, S., Lanvin, B.

Yan, Z., Shi, R. \& Zhiming, Y. (2018). ICT Development and Sustainable Energy Consumption: A Perspective of Energy Productivity. Sustainability, 10(7), 2568, doi:10.3390/su10072568 